UNDERGRADUATE RESEARCH IN NATURAL AND CLINICAL SCIENCE AND TECHNOLOGY (URNCST) JOURNAL Read more URNCST Journal articles and submit your own today at: https://www.urncst.com

\title{
The Relationship between Using Cannabis, Consuming Isothiocyanate Rich Broccoli, and HDAC Expression in Schizophrenia: A Research Protocol
}

\author{
Natasha J. Verhoeff, BHSc Student [1], Saihajleen K. Dhillon, BHSc Student [1] \\ [1] Faculty of Health Sciences, McMaster University, Hamilton, Ontario, Canada L8S 4L8 \\ *Corresponding Author: verhoefn@mcmaster.ca
}

\begin{abstract}
"Research in Earnest"

Schizophrenia is a chronic brain disorder which affects the thoughts, feelings, and behaviour of people. According to current studies, there is a relationship between schizophrenia severity and amounts of the epigenetic marking histone acetylation in the brain. As histone acetylation increases, gene expression increases. Persons with schizophrenia show elevated histone deacetylase expression which leads to reduced amounts of acetyl markings and subsequent tightening of the chromatin structure. Additionally, $\Delta 9$-tetrahydrocannabinol, a psychoactive compound present in cannabis, has been found to also cause increased histone deacetylase levels, and several studies have shown a relationship between using cannabis and the development or worsening of schizophrenia, however, the exact molecular mechanisms are unknown. Isothiocyanates, a class of organic compounds found in vegetables like broccoli, have been found to be histone deacetylase inhibitors. This study will test the relationship between cannabis, isothiocyanates, and schizophrenia at the genetic level by using normal and Disrupted in Schizophrenia 1 mice, and Chromatin Immunoprecipitation, Sequencing, Reverse Transcription Quantitative Polymerase Chain Reaction, and Western Blot. These tests will be conducted in mice before they are conducted in humans in order to first confirm that the following relationship exists. It is hypothesized that if mice eat broccoli sprouts, their histone deacetylase will be inhibited, genes responsible for cognitive function will be euchromatin, and they will have improved cognition and functional outcomes. It is also hypothesized that if mice are exposed to $\Delta 9$-tetrahydrocannabinol, their histone deacetylase will be more active, genes responsible for cognitive function will be heterochromatin, and there may be a higher chance of the development or worsening of schizophrenia. Depending on which genes are affected and how much they are affected, understanding an epigenetic relationship between cannabis and schizophrenia may help determine why it can be harmful, and how molecules like isothiocyanates can potentially reduce the harm.
\end{abstract}

URNCST Journal

Keywords: broccoli; cannabis; epigenetics; genetics; isothiocyanates; neurobiology; schizophrenia; tetrahydrocannabinol

\section{Introduction}

Schizophrenia is a chronic, mental disorder that affects the thoughts, feelings, and behaviour of people [1]. Approximately $1.1 \%$ of the world's population has schizophrenia [2]. Persons with schizophrenia may experience positive, negative and cognitive symptoms [1]. The positive symptoms associated with schizophrenia include hallucinations, delusions, thought disorders, and movement disorders [1]. The negative symptoms include reduced expression of emotions, reduced feelings of pleasure, difficulty sustaining activities and reduced speaking [1]. The cognitive symptoms include poor executive functioning, trouble focusing, and problems with "working memory" [1]. Schizophrenia can develop both due to inherited genes (genetics) and environmental factors that alter gene expression (epigenetics) [1].

There is a correlation between schizophrenia and the amount of epigenetic histone acetylation [3, 4]. Histone acetylation is transcriptionally activating because negatively charged acetyl groups added to positively charged lysine in histones make it difficult for the histones to attract the phosphate backbone of the deoxyribonucleic acid (DNA), so the DNA opens up and becomes more accessible [5]. Higher accessibility of DNA enables polymerases to more easily bind to the DNA and carry out transcription to express certain genes [5]. Persons with schizophrenia have higher expression of histone deacetylase (HDAC), which results in erased acetyl markings, and decreased expression of genes [6]. This may result in poor psychological outcomes since the genes with reduced expression may be associated with cognition.

It has been shown that isothiocyanates such as sulforaphane (SFN) inhibit HDAC activity [7-10]. A study concluded that HDAC inhibitors are considered to be good targets for new therapeutic drug development since overexpression of HDAC in schizophrenic patients causes transcriptional repression in a variety of genes [4].

It has also been shown that SFN has the potential to improve cognition in schizophrenic patients [11]. 
UNDERGRADUATE RESEARCH IN NATURAL AND CLINICAL SCIENCE AND TECHNOLOGY (URNCST) JOURNAL Read more URNCST Journal articles and submit your own today at: https://www.urncst.com

In a previous study, 7 outpatients with schizophrenia took 3 tablets of $30 \mathrm{mg}$ of (SFN)-glucosinolate, a HDAC inhibiting isothiocyanate, per day for 8 weeks and after measuring the effect on cognition using the Japanese version of the CogState battery, it was concluded that SFN had the potential to improve their cognitive function [12]. Another study administered SFN to PCP-induced mice models of schizophrenia for 10 days. It was found that the performance of the PCP-induced mice on the novel object recognition test (NORT), which is a cognitive test that measures learning and memory in mice, was significantly better after treatment with SFN [13]. Additionally, a review article mentioned that SFN doses that can feasibly be obtained in the diet improved cognition in humans with psychosis and increased their expression of brain-derived neurotrophic factor (BDNF) [14]. Furthermore, a study in mice found that dietary glucoraphanin, the precursor to SFN, prevents the onset of psychosis in the offspring after maternal immune activation (MIA) [15].

Moreover, even though there has been very little research on schizophrenia and increased HDAC expression due to cannabis, several studies have found a relationship between cannabis and HDAC activity. A previous study found that $\Delta 9$-tetrahydrocannabinol (THC), a psychoactive compound present in cannabis, increased expression of HDAC3 in a dose dependent manner [16]. This is especially relevant since HDAC3 is the most highly expressed class I HDAC in the brain, predominantly expressed in the hippocampus, cortex, and cerebellum [17]. Additionally, a study testing mice with genetic susceptibility to schizophrenia found that THC caused an exaggerated presentation of schizophrenic symptoms which may be due to the down regulation of the gene BDNF in those mice [18]. Furthermore, a study found that the hippocampi of mice who were prenatally administered with methylazoxymethanol acetate (MAM) in order to become schizophrenia-like models showed $\mathrm{H} 3 \mathrm{~K} 9$ deacetylation that was regulated by an increase in both HDAC1 and HDAC3 [19]. The study also found that the schizophrenia-like brains whose hippocampi were treated with the cannabinoid receptor-1 inverse agonist AM251 had H3K9 acetylation expression at the level observed in typical brains [19]. Since AM251 is an inverse agonist at the cannabinoid-1 receptor, it acts in the opposite way from the THC in cannabis [19]. Therefore, schizophrenia-like brains may inherently have an effect like cannabis, and cannabis exposure may be associated with an increase in HDAC.

To examine an epigenetic relationship between schizophrenia, consuming broccoli sprouts (which contain the isothiocyanate SFN), and using cannabis, the following will be investigated in control and schizophrenia-model mice:

1. Whether exposure to THC in cannabis, which is known to increase HDAC expression, causes decreased acetylation in genes, which genes acetylate less, and which genes and proteins are expressed less.

2. Whether administration of HDAC-inhibiting isothiocyanates causes higher acetylation in genes, which genes acetylate more, and which genes and proteins are expressed more.

Broccoli sprouts are the isothiocyanates used in this proposal as these contain the highest concentration of glucoraphanin which is a precursor to the isothiocyanate SFN [20]. In addition, broccoli sprouts are natural, relatively inexpensive, and easily obtainable [21]. Furthermore, the first principle of medicine is "Do no harm" [22]. Broccoli sprouts, as a therapeutic agent, would have little adverse side effects in comparison to medications and they have multiple active ingredients and antioxidants, thus, they could have other positive health effects [7].

This research proposal is innovative since the effects of both isothiocyanates and cannabis on HDAC activity in relation to schizophrenia have been under-studied, and this proposal is unique as it is most interested in the importance of acetylation in the entire genome and how increased and decreased acetylation affects gene and protein expression in schizophrenic model mice. Knowing this relationship could improve the lives of people prone to schizophrenia by identifying an epigenetic way in which cannabis may be harmful and worsen schizophrenia, while isothiocyanates may reduce this harm and act as a therapeutic agent.

\section{Methods}

Experimental Conditions

Seven-month-old mice receiving the same food and living in the same laboratory environment would be used. Twelve mice of the following categories would be used: normal, Disrupted in Schizophrenia-1 (DISC1), normal administered broccoli sprouts, DISC1 administered broccoli sprouts, normal injected with THC and DISC1 injected with THC. Those given broccoli sprouts would receive $20 \mathrm{~g} / \mathrm{kg}$ at $12 \mathrm{pm}$ daily for ten consecutive days. This dose was chosen based on the dose a previous study used in order to measure how broccoli sprout consumption affects mouse HDAC expression [23]. Those injected with cannabis would receive $10 \mathrm{mg} / \mathrm{kg}$ of THC at $12 \mathrm{pm}$ daily for 10 consecutive days. This dose of THC is based on what a previous study that looked at THC exposure effects on BDNF levels in DISC1 mice used [24]. All tests would occur on the eleventh day. The administration time interval was chosen based on a previous study looking at the impact of SFN on cognition in mice and a study measuring BDNF levels after THC exposure to DISC1 mice [13, 18]. These experimental conditions and the subsequent tests that would be administered are outlined in (Figure 1). 
UNDERGRADUATE RESEARCH IN NATURAL AND CLINICAL SCIENCE AND TECHNOLOGY (URNCST) JOURNAL Read more URNCST Journal articles and submit your own today at: https://www.urncst.com

\section{Overview of Experiment}

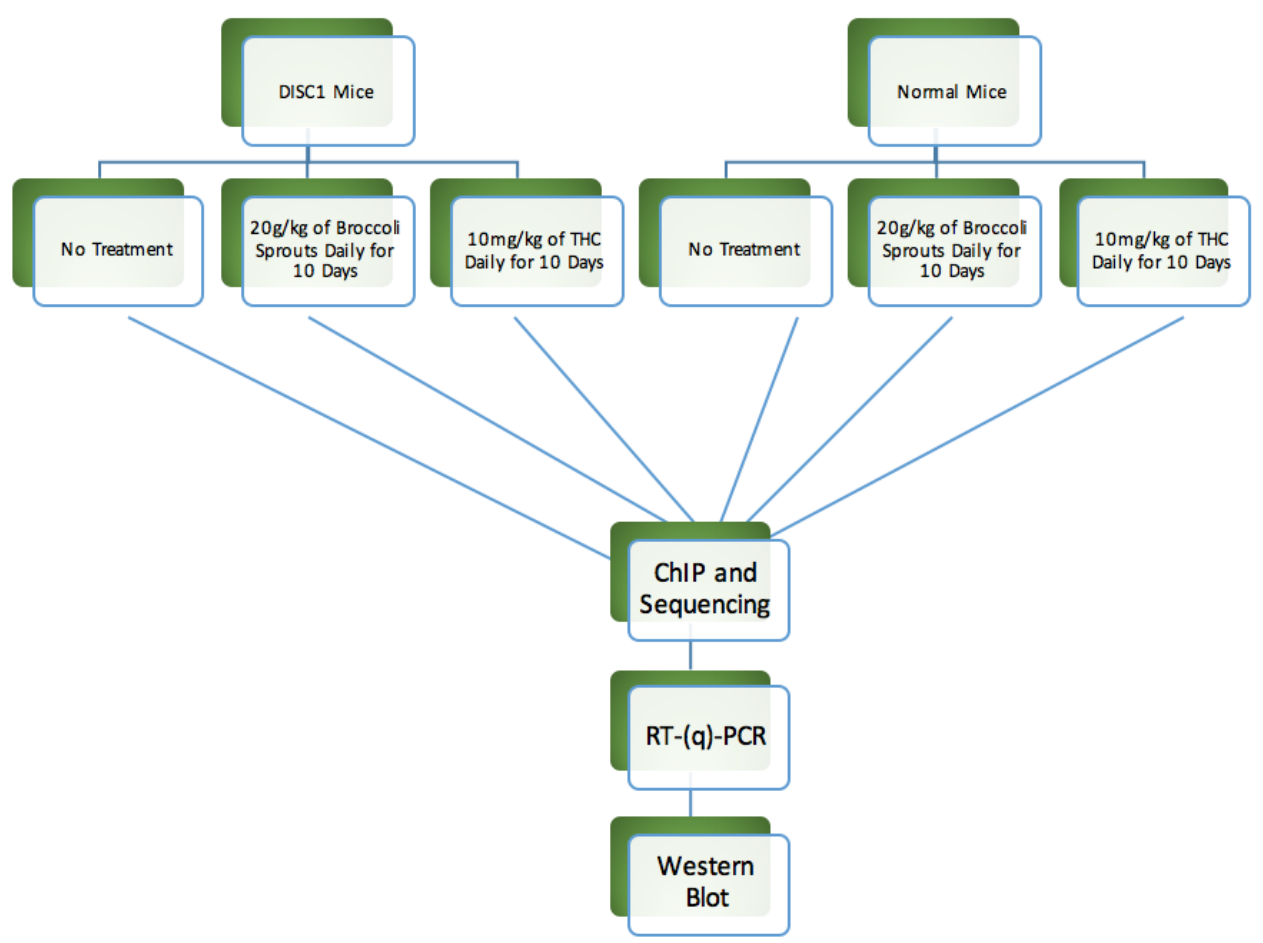

Figure 1: Treatment Groups and Experimental Design

DISC1 $=$ Disrupted in Schizophrenia-1; $\mathrm{THC}=\Delta 9$-Tetrahydrocannabinol; $\mathrm{ChIP}=$ Chromatin immunoprecipitation; RT-(q)-PCR= Reverse transcription quantitative polymerase chain reaction

Tests to Measure Acetylation Levels and mRNA and Protein Expression

1. Chromatin immunoprecipitation (ChIP) and Sequencing are optimal experiments to investigate the specific location in the genome that acetylation is associated with. A ChIP-validated antibody that only detects acetylation would be used to immunoprecipitate and isolate acetylation and eliminate all other unrelated cellular material [25]. Using a genome database, the identified acetylated genes would be examined to see if they are related to cognition [26]. Drawbacks of ChIP include antibodies not fully binding to all of the acetylated segments, and antibody removal during the washing step [25].

2. Reverse transcription quantitative polymerase chain reaction (RT-(q) PCR) is optimal to quantitatively detect mRNA expression of each gene individually that proved to be acetylated in the ChIP and Sequencing. After reverse transcription, PCR would be used to amplify the DNA amount quantitatively [27]. Then, the fold change would be calculated to assess gene expression changes [27]. A drawback of RT-(q) PCR is that, because it is highly sensitive, a slight contamination of DNA can cause a large variability in results [27].
3. Western blot is optimal to analyze protein expression of the genes that proved to be acetylated in the ChIP and Sequencing. This test is needed since factors like microRNA may prevent translation to protein [28]. Antibodies would be added to detect each protein of interest, and produce light which allows for the protein to be detected and imaged [28]. The thickness of the band in the western blot data analysis would show how much the protein is expressed [28]. A drawback of western blot is that it requires testing each protein individually [28].

\section{Statistical Analysis}

Upon completion of the tests above, statistical tests, such as analysis of variance (ANOVA) and unpaired T-tests, would be conducted in order to note statistically significant differences amongst the different study groups in the 3 stages: ChIP, RT-(q) PCR, and western blot [29]. Data would be tested as to whether they meet requirements of normal distributions (via skewness, curtosis, outliers and homogeneity of variance), and if certain data do not meet those requirements, logarithmic transformations would be applied, marked outliers would be left out, or nonparametric tests (such as Mann-Whitney U-tests) would be used [29]. Bonferroni correction for 
UNDERGRADUATE RESEARCH IN NATURAL AND CLINICAL SCIENCE AND TECHNOLOGY (URNCST) JOURNAL Read more URNCST Journal articles and submit your own today at: https://www.urncst.com

multiple comparisons would be applied where appropriate [29].

\section{Results}

The study proposed by this protocol has not been started yet. Therefore, results are not available. Genes that are related to cognition, are expressed less in schizophrenia, and are expected to be affected by the treatments in this study include: VRK2 which codes for a protein that effects signaling pathways, OXTR which codes for the oxytocin receptor, BRD1 which codes for a protein that is a transcriptional regulator, COMT which codes for an enzyme that degrades catecholamines, and PGC-1 $\alpha$ and NRF-1 which code for proteins that are transcriptional activators for genes involved in energy metabolism [30-34]. (Tables 1- 3) outline expected and other possible results. (Figure 2) also outlines expected results.

Table 1: ChIP and Sequencing: Expected and Other Possible Results

\begin{tabular}{|l|l|l|}
\hline Mice Comparison & Expected Result (Benchmark for Success) & Other Possible Results \\
\hline $\begin{array}{l}\text { Normal versus DISC1 } \\
\text { for all treatments } \\
\text { no treatment, broccoli } \\
\text { sprouts, and THC) }\end{array}$ & $\begin{array}{l}\text { Distinctly } \uparrow \text { levels of acetylated genes in } \\
\text { normal mice compared to DISC1 mice } \\
\text { That the genes acetylated are related to } \\
\text { improving cognitive functioning }\end{array}$ & $\begin{array}{l}\text { Similar or } \downarrow \text { levels of acetylated genes in } \\
\text { normal mice compared to DISC1 mice } \\
\text { That only some or none of the genes } \\
\text { acetylated are related to improving cognitive } \\
\text { functioning }\end{array}$ \\
\hline $\begin{array}{l}\text { Normal versus Normal } \\
\text { that ate broccoli } \\
\text { sprouts }\end{array}$ & $\begin{array}{l}\uparrow \text { Acetylated genes in normal mice that ate } \\
\text { broccoli sprouts compared to normal mice } \\
\text { that did not }\end{array}$ & $\begin{array}{l}\text { Similar or } \downarrow \text { acetylated genes in normal mice } \\
\text { that ate broccoli sprouts compared to normal } \\
\text { mice that did not }\end{array}$ \\
\hline $\begin{array}{l}\text { DISC1 versus DISC1 } \\
\text { that ate broccoli } \\
\text { sprouts }\end{array}$ & $\begin{array}{l}\uparrow \text { Acetylated genes in DISC1 mice that ate } \\
\text { broccoli sprouts compared to DISC1 mice } \\
\text { that did not }\end{array}$ & $\begin{array}{l}\text { Similar or } \downarrow \text { acetylated genes in DISC1 mice } \\
\text { that ate broccoli sprouts compared to DISC1 } \\
\text { mice that did not }\end{array}$ \\
\hline $\begin{array}{l}\text { Normal versus Normal } \\
\text { that were injected } \\
\text { with THC }\end{array}$ & $\begin{array}{l}\downarrow \text { Acetylated genes in normal mice that were } \\
\text { injected with THC compared to normal mice }\end{array}$ & $\begin{array}{l}\text { Similar or } \uparrow \text { acetylated genes in normal mice } \\
\text { that were injected with THC compared to } \\
\text { normal mice that were not }\end{array}$ \\
\hline $\begin{array}{l}\text { DISC1 versus DISC1 } \\
\text { that were injected } \\
\text { with THC }\end{array}$ & $\begin{array}{l}\downarrow \text { Acetylated genes in DISC1 mice that were } \\
\text { injected with THC compared to DISC1 mice } \\
\text { that were not }\end{array}$ & $\begin{array}{l}\text { Similar or } \uparrow \text { acetylated genes in DISC1 mice } \\
\text { that were injected with THC compared to } \\
\text { DISC1 mice that were not }\end{array}$ \\
\hline
\end{tabular}

DISC1 $=$ Disrupted in Schizophrenia-1; THC $=\Delta$ 9-Tetrahydrocannabinol

Table 2: RT-(q) PCR: Expected and Other Possible Results

\begin{tabular}{|l|l|l|}
\hline Mice Comparison & Expected Result (Benchmark for Success) & Other Possible Results \\
\hline $\begin{array}{l}\text { Normal versus DISC1 } \\
\text { for all treatments } \\
\text { (no treatment, } \\
\text { broccoli sprouts, } \\
\text { and THC) }\end{array}$ & $\begin{array}{l}\uparrow \text { Expression of cognitive enhancing genes in } \\
\text { the normal mice compared to DISC1 mice }\end{array}$ & $\begin{array}{l}\text { Similar or } \downarrow \text { expression of cognitive enhancing } \\
\text { genes in the normal mice compared to DISC1 } \\
\text { mice } \\
\text { Some genes that normally improve cognitive } \\
\text { function, when overexpressed, may impair } \\
\text { cognitive function }\end{array}$ \\
\hline $\begin{array}{l}\text { Normal versus } \\
\text { bormal that ate }\end{array}$ & $\begin{array}{l}\uparrow \text { Expression of cognitive enhancing genes in } \\
\text { the normal mice that ate broccoli sprouts } \\
\text { compared to normal mice that did not }\end{array}$ & $\begin{array}{l}\text { Similar or } \downarrow \text { expression of cognitive enhancing } \\
\text { genes in normal mice that ate broccoli sprouts } \\
\text { compared to normal mice that did not }\end{array}$ \\
\hline $\begin{array}{l}\text { DISC1 versus DISC1 } \\
\text { that ate broccoli } \\
\text { sprouts }\end{array}$ & $\begin{array}{l}\uparrow \text { Expression of cognitive enhancing genes in } \\
\text { the DISC1 mice that ate broccoli sprouts } \\
\text { compared to DISC1 mice that did not }\end{array}$ & $\begin{array}{l}\text { Similar or } \downarrow \text { expression of cognitive enhancing } \\
\text { genes in DISC1 mice that ate broccoli sprouts } \\
\text { compared to DISC1 mice that did not }\end{array}$ \\
\hline $\begin{array}{l}\text { Normal versus } \\
\text { Normal that were } \\
\text { injected with THC }\end{array}$ & $\begin{array}{l}\downarrow \text { Expression of cognitive enhancing genes in } \\
\text { the normal mice that were injected with THC } \\
\text { compared to normal mice that were not }\end{array}$ & $\begin{array}{l}\text { Similar or } \uparrow \text { expression of cognitive enhancing } \\
\text { genes in normal mice that were injected with } \\
\text { THC compared to normal mice that were not }\end{array}$ \\
\hline
\end{tabular}


UNDERGRADUATE RESEARCH IN NATURAL AND CLINICAL SCIENCE AND TECHNOLOGY (URNCST) JOURNAL Read more URNCST Journal articles and submit your own today at: https://www.urncst.com

\begin{tabular}{|l|l|l|}
\hline $\begin{array}{l}\text { DISC1 versus DISC1 } \\
\text { that were injected } \\
\text { with THC }\end{array}$ & $\begin{array}{l}\downarrow \text { Expression of cognitive enhancing genes in } \\
\text { the DISC1 mice that were injected with THC } \\
\text { compared to DISC1 mice that were not }\end{array}$ & $\begin{array}{l}\text { Similar or } \uparrow \text { expression of cognitive enhancing } \\
\text { genes in DISC1 mice that were injected with } \\
\text { THC compared to DISC1 mice that were not }\end{array}$ \\
\hline
\end{tabular}

DISC1 $=$ Disrupted in Schizophrenia-1; $\mathrm{THC}=\Delta$ 9-Tetrahydrocannabinol

Table 3: Western blot: Expected and Other Possible Results

\begin{tabular}{|l|l|l|}
\hline Mice Comparison & Expected Result (Benchmark for Success) & Other Possible Results \\
\hline $\begin{array}{l}\text { Normal versus DISC1 } \\
\text { for all treatments (no } \\
\text { treatment, broccoli } \\
\text { sprouts, and THC) }\end{array}$ & $\begin{array}{l}\uparrow \text { Expression of cognitive enhancing proteins } \\
\text { in the normal mice compared to DISC1 mice }\end{array}$ & $\begin{array}{l}\text { Similar or } \downarrow \text { expression of cognitive enhancing } \\
\text { proteins in the normal mice compared to DISC1 } \\
\text { mice } \\
\text { Some proteins that normally improve cognitive } \\
\text { function, when overexpressed, may impair } \\
\text { cognitive function }\end{array}$ \\
\hline $\begin{array}{l}\text { Normal versus } \\
\text { Normal that ate } \\
\text { broccoli sprouts }\end{array}$ & $\begin{array}{l}\uparrow \text { Expression of cognitive enhancing proteins in } \\
\text { the normal mice that ate broccoli sprouts } \\
\text { compared to normal mice that did not }\end{array}$ & $\begin{array}{l}\text { Similar or } \downarrow \text { expression of cognitive enhancing } \\
\text { proteins in normal mice that ate broccoli } \\
\text { sprouts compared to normal mice that did not }\end{array}$ \\
\hline $\begin{array}{l}\text { DISC1 versus DISC1 } \\
\text { that ate broccoli } \\
\text { sprouts }\end{array}$ & $\begin{array}{l}\uparrow \text { Expression of cognitive enhancing proteins in } \\
\text { the DISC1 mice that ate broccoli sprouts } \\
\text { compared to DISC1 mice that did not }\end{array}$ & $\begin{array}{l}\text { Similar or } \downarrow \text { expression of cognitive enhancing } \\
\text { proteins in DISC1 mice that ate broccoli } \\
\text { sprouts compared to DISC1 mice that did not }\end{array}$ \\
\hline $\begin{array}{l}\text { Normal versus } \\
\text { Normal that were } \\
\text { injected with THC }\end{array}$ & $\begin{array}{l}\downarrow \text { Expression of cognitive enhancing proteins in } \\
\text { the normal mice that were injected with THC } \\
\text { compared to normal mice that were not }\end{array}$ & $\begin{array}{l}\text { Similar or } \uparrow \text { expression of cognitive enhancing } \\
\text { proteins in normal mice that were injected } \\
\text { with THC compared to normal mice that } \\
\text { were not }\end{array}$ \\
\hline $\begin{array}{l}\text { DISC1 versus DISC1 } \\
\text { that were injected } \\
\text { with THC }\end{array}$ & $\begin{array}{l}\downarrow \text { Expression of cognitive enhancing proteins in } \\
\text { the DISC1 mice that were injected with THC } \\
\text { compared to DISC1 mice that were not }\end{array}$ & $\begin{array}{l}\text { Similar or } \uparrow \text { expression of cognitive enhancing } \\
\text { proteins in DISC1 mice that were injected with } \\
\text { THC compared to DISC1 mice that were not }\end{array}$ \\
\hline
\end{tabular}

DISC1 $=$ Disrupted in Schizophrenia-1; $\mathrm{THC}=\Delta$ 9-Tetrahydrocannabinol

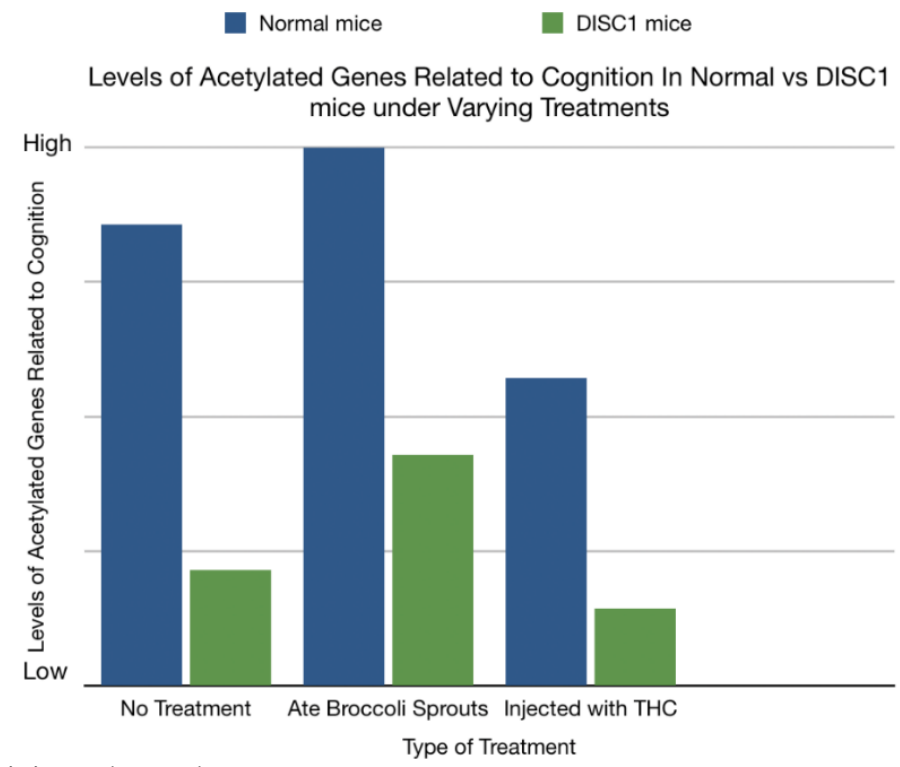

Figure 2: Sample Graph of Anticipated Results 
UNDERGRADUATE RESEARCH IN NATURAL AND CLINICAL SCIENCE AND TECHNOLOGY (URNCST) JOURNAL Read more URNCST Journal articles and submit your own today at: https://www.urncst.com

\section{Discussion}

Knowing the relationship between broccoli sprouts, cannabis and HDAC expression in schizophrenia could improve the lives of persons with schizophrenia by reducing their symptoms and increasing their brain function. The anticipated results from the results section would be met if the acetylated genes are significant for cognitive functioning, and those genes and the proteins they code for are more expressed in normal mice compared to DISC1 mice, and in mice that eat broccoli sprouts compared to mice that do not or are injected with THC. If those benchmarks are met, and if future pre-clinical and clinical studies support these findings, a clinical implication could be a recommendation that persons with schizophrenia eat higher quantities of broccoli sprouts, which would act as an easy and safe treatment decreasing their disabling cognitive symptoms. It could also potentially be recommended that persons with schizophrenia avoid using cannabis as exposure to the drug may increase their symptoms by causing even more HDAC activity. If persons with schizophrenia do continue to use cannabis, they could eat broccoli sprouts to potentially reverse the effect by decreasing HDAC activity. Additionally, as a preventative measure, it could potentially be recommended that people more susceptible to developing schizophrenia eat more broccoli sprouts and avoid using cannabis so that their HDAC activity does not reach levels as much increased as in persons with schizophrenia.

A limitation of this study is that it only tests the effect of THC, the psychoactive component of cannabis. Another main and active ingredient in cannabis is cannabidiol (CBD) which could have a confounding effect when administered with THC [35]. Thus, the results of this study may be more applicable to people who use cannabis with a high THC composition. A future study could examine the effect that CBD alone, or CBD combined with THC, has on HDAC activity and the expression of genes that may be important for cognition. This would be relevant for persons with schizophrenia who use or will use medicinal cannabis which is usually made from CBD-dominant strains and has little or no THC [35]. Additionally, broccoli sprouts are used in this study since they have the highest levels of glucoraphanin which is the precursor to SFN [36]. However, there are other cruciferous vegetables such as cabbage, cauliflower, and kale that contain glucoraphanin as well [36]. Future studies could test the effect of the other glucoraphanin containing cruciferous vegetables on schizophrenia symptoms since these may be preferable over broccoli sprouts for some people, and in rare cases people may have an allergy towards broccoli [37].

\section{Conclusion}

In conclusion, researching the epigenetic relationships between cannabis, isothiocyanates and gene expression in relation to schizophrenia is relevant since over 115,000 Canadians have schizophrenia [2]. With the recent legalization of cannabis in Canada, better understanding of how cannabis may harmfully affect cognitive enhancing gene expression, and how eating broccoli sprouts, which have little adverse effects, may reduce these negative effects, is important to improve the lives of people prone to schizophrenia. Future steps for this study include conducting it in mice first and then, if the predicted outcomes are found, conducting it in humans to see the direct effects in the target population.

\section{List of Abbreviations}

ANOVA: Analysis of variance

BDNF: Brain-derived neurotrophic factor

CBD: Cannabidiol

ChIP: Chromatin immunoprecipitation

DISC1: Disrupted in Schizophrenia-1

DNA: Deoxyribonucleic acid

HDAC: Histone deacetylase

MAM: Methylazoxymethanol acetate

MIA: Maternal immune activation

NORT: Novel object recognition test

RT- (q) PCR: Reverse transcription quantitative

polymerase chain reaction

SFN: Sulforaphane

THC: $\Delta$ 9-Tetrahydrocannabinol

\section{Conflicts of Interest}

The authors declare that they have no conflict of interests.

\section{Ethics Approval}

This article did not require ethics approval or participant consent as it was a proposal and no human participants, animals, tissue, or data were used. If this study were to be conducted, ethics approval from the research ethics board of the institution where the study would be conducted would be required.

\section{Authors' Contributions}

NJV: made substantial contributions to the conception and design of the work and the acquisition, analysis and interpretation of data for the work in addition to drafting the manuscript and revising it critically, and giving approval for the final version to be published.

SKD: contributed to the acquisition of data for the work, revised the work critically for important intellectual content, and approved of the final version to be published.

\section{Acknowledgements}

We would like to thank SciNapse Undergraduate Science Case Competition (USCC) for supporting this research proposal, and granting us with the opportunity to investigate a solution for the current global health concern about whether cannabis is harmful. We would also like to thank SciNapse at McMaster University for providing us with feedback which helped us succeed as competition finalists and give a poster presentation of our research at the University of Ottawa. 
UNDERGRADUATE RESEARCH IN NATURAL AND CLINICAL SCIENCE AND TECHNOLOGY (URNCST) JOURNAL Read more URNCST Journal articles and submit your own today at: https://www.urncst.com

\section{Funding}

This study was not funded.

\section{References}

[1] Schizophrenia. National Institute of Mental Health. U.S. Department of Health and Human Services; [cited 2019 Oct 14]. Available from: https://www.nimh.nih.gov/health/topics/schizophrenia/ index.shtml

[2] About Schizophrenia. Sardaa. [cited 2020 Jan 12]. Available from: https://sardaa.org/resources/aboutschizophrenia/

[3] Ibi D, González-Maeso J. Epigenetic signaling in schizophrenia. Cellular Signalling. 2015 Oct; 27(10):2131-6. https://doi.org/10.1016/j.cellsig.2015.06.003

[4] Shorter KR, Miller BH. Epigenetic mechanisms in schizophrenia. Progress in Biophysics and Molecular Biology. 2015 Jul;118(1-2):1-7. https://doi.org/10.1016/j.pbiomolbio.2015.04.008

[5] Gräff J, Tsai L-H. The Potential of HDAC Inhibitors as Cognitive Enhancers. Annual Review of Pharmacology and Toxicology. 2013 Jun;53(1):311-30. https://doi.org/10.1146/annurev-pharmtox011112-140216

[6] Akbarian S. Epigenetic mechanisms in schizophrenia. Dialogues in clinical neuroscience. 2014 Sep; 16(3): 405-417.

[7] Bricker GV, Riedl KM, Ralston RA, Tober KL, Oberyszyn TM, Schwartz SJ. Isothiocyanate metabolism, distribution, and interconversion in mice following consumption of thermally processed broccoli sprouts or purified sulforaphane. Molecular Nutrition \& Food Research. 2014;58(10):1991-2000. Available from: https://doi.org/10.1002/mnfr.201400104

[8] Cha DS, Kudlow PA, Baskaran A, Mansur RB, Mcintyre RS. Implications of epigenetic modulation for novel treatment approaches in patients with schizophrenia. Neuropharmacology. 2014 Feb;77:481-486. Available from: https://www.sciencedirect.com/science/article/abs/pii/ $\underline{\text { S0028390813004061?via=ihub }}$

[9] Myzak MC, Dashwood WM, Orner GA, Ho E, Dashwood RH. Sulforaphane inhibits histone deacetylase in vivo and suppresses tumorigenesis in Apcmin mice. The FASEB Journal. 2006;20(3): 506-8. Available from: https://www.ncbi.nlm.nih.gov/pmc/articles/ PMC2373266

[10] Tortorella SM, Royce SG, Licciardi PV, Karagiannis TC. Dietary Sulforaphane in Cancer Chemoprevention: The Role of Epigenetic Regulation and HDAC Inhibition. Antioxidants \& Redox Signaling. 2015 Jun;22(16):1382-424. Available from: https://www.ncbi.nlm.nih.gov/pmc/articles/ PMC4432495/

[11] Yang Y, Li R, Hei G, Wu R. Role of sulforaphane in improving negative symptoms and cognitive symptoms of schizophrenia and the underlying mechanism.

Journal of central south university. 2019 Jun 28;44(6):701-5. Available from:

http://www.csumed.com/xbwk/CN/10.11817/j.issn. 1672-7347.2019.06.014

[12] Shiina A, Kanahara N, Sasaki T, Oda Y, Hashimoto T, Hasegawa T, et al. An Open Study of Sulforaphanerich Broccoli Sprout Extract in Patients with Schizophrenia. Clinical Psychopharmacology and Neuroscience. 2015;13(1):62-7. https://doi.org/10.9758/cpn.2015.13.1.62

[13] Shirai Y, Fujita Y, Hashimoto R, Ohi K, Yamamori H, Yasuda Y, et al. Dietary Intake of Sulforaphane-Rich Broccoli Sprout Extracts during Juvenile and Adolescence Can Prevent PhencyclidineInduced Cognitive Deficits at Adulthood. Plos One. 2015;10(6). Available from: https://www.ncbi.nlm.nih.gov/pmc/articles/ PMC4479552/pdf/pone.0127244.pdf

[14] Aucoin M, Lachance L, Cooley K, Kidd S. Diet and Psychosis: A Scoping Review. Neuropsychobiology. 2018;1-23. Available from: https://www.karger.com/Article/FullText/493399

[15] Matsuura A, Ishima T, Fujita Y, Iwayama Y, Hasegawa S, Kawahara-Miki R, et al. Dietary glucoraphanin prevents the onset of psychosis in the adult offspring after maternal immune activation. Scientific Reports. 2018 Jan;8(1). Available from: https://www.ncbi.nlm.nih.gov/pmc/articles/ PMC5794794/

[16] Khare M, Taylor A, Konje J, Bell S. $\Delta 9$ Tetrahydrocannabinol inhibits cytotrophoblast cell proliferation and modulates gene transcription. Molecular Human Reproduction. 2006;12(5):321-33. Available from: https://academic.oup.com/molehr/article/12/5/321/ 1005728

[17] Wey H-Y, Gilbert TM, Zürcher NR, She A, Bhanot A, Taillon BD, et al. Insights into neuroepigenetics through human histone deacetylase PET imaging. Science Translational Medicine. 2016 Oct;8(351). Available from: https://www.ncbi.nlm.nih.gov/pmc/articles/ PMC5784409/

[18] Could smoking marijuana trigger schizophrenia?. Sackler Faculty of Medicine | Tel Aviv University. [cited 2019 Oct 14]. Available from: https://en-med.tau.ac.il/news/marijuana_schizophrenia

[19] Večeřa J, Bártová E, Krejčí J, Legartová S, Komůrková D, Rudá-Kučerová J, et al. HDAC1 and HDAC3 underlie dynamic $\mathrm{H} 3 \mathrm{~K} 9$ acetylation during embryonic 
UNDERGRADUATE RESEARCH IN NATURAL AND CLINICAL SCIENCE AND TECHNOLOGY (URNCST) JOURNAL Read more URNCST Journal articles and submit your own today at: https://www.urncst.com

neurogenesis and in schizophrenia-like animals. Journal of Cellular Physiology. 2017 Mar; 233(1): 530-48. https://doi.org/10.1002/jcp.25914

[20] Houghton CA, Fassett RG, Coombes JS. Sulforaphane: translational research from laboratory bench to clinic. Nutrition Reviews. 2013;71(11):709-26. Available from: https://academic.oup.com/nutritionreviews/ article/71/11/709/1820866

[21] What are the Cheapest Vegetables Per Pound?. My Money Blog. 2017 [cited 2020 Jan 12]. Available from: http://www.mymoneyblog.com/cheapestvegetables.html

[22] Shmerling RH. First, do no harm. Harvard Health Blog. 2015 [cited 2020 Jan 12]. Available from: http://www.health.harvard.edu/blog/first-do-no-harm201510138421

[23] Beaver LM, Löhr CV, Clarke JD, Glasser ST, Watson GW, Wong CP, et al. Broccoli Sprouts Delay Prostate Cancer Formation and Decrease Prostate Cancer Severity with a Concurrent Decrease in HDAC3 Protein Expression in Transgenic Adenocarcinoma of the Mouse Prostate (TRAMP) Mice. Current Developments in Nutrition. 2017;2(3). Available from: https://www.ncbi.nlm.nih.gov/pmc/articles/ PMC6041877/

[24] Segal-Gavish H, Gazit N, Barhum Y, Ben-Zur T, Taler M, Hornfeld SH, et al. BDNF overexpression prevents cognitive deficit elicited by adolescent cannabis exposure and host susceptibility interaction. Human Molecular Genetics. 2017 Nov; 26(13): 2462-71. Available from: https://www.ncbi.nlm.nih.gov/ pmc/articles/PMC6251614/

[25] Chromatin IP (ChIP Assays): Thermo Fisher Scientific US. Chromatin IP (ChIP Assays) | Thermo Fisher Scientific - US. [cited 2019 Oct 14]. Available from: https://www.thermofisher.com/ca/en/home/lifescience/protein-biology/protein-biology-learningcenter/protein-biology-resource-library/pierce-proteinmethods/chromatin-ip-chip-assays.html

[26] DNA Sequencing Fact Sheet. Genome.gov. [cited 2019 Oct 14]. Available from: https://www.genome.gov/10001177/dna-sequencingfact-sheet/

[27] Basic Principles of RT-qPCR. Thermo Fisher Scientific - US. [cited 2019 Oct 14]. Available from: https://www.thermofisher.com/ca/en/home/brands/ thermo-scientific/molecular-biology/molecularbiology-learning-center/molecular-biology-resourcelibrary/spotlight-articles/basic-principles-rt-qpcr.html

[28] Western blot. Learn: western blot - The Human Protein Atlas. [cited 2019 Oct 14]. Available from: http://www.proteinatlas.org/learn/method/western

[29] Hazra A, Gogtay N. Biostatistics series module 3: Comparing groups: Numerical variables. Indian Journal of Dermatology. 2016;61(3):251. Available from: https://www.ncbi.nlm.nih.gov/pmc/articles/ PMC4885176/

[30] Tesli M, Wirgenes KV, Hughes T, Bettella F, Athanasiu L, Hoseth ES, et al. VRK2 gene expression in schizophrenia, bipolar disorder and healthy controls. British Journal of Psychiatry. 2016;209(2):114-20. Available from: https://www.cambridge.org/core/services/ aop-cambridge-core/content/view/ 90E360F7B1C9A6E237C0861DE6465CC7/ S0007125000244565a.pdf/ vrk2 gene expression in schizophrenia bipolar disorder_and_healthy_controls.pdf

[31] Uhrig S, Hirth N, Broccoli L, Wilmsdorff MV, Bauer M, Sommer C, et al. Reduced oxytocin receptor gene expression and binding sites in different brain regions in schizophrenia: A post-mortem study. Schizophrenia Research. 2016;177(1-3):59-66. Available from: https://www.sciencedirect.com/science/article/abs/pii/ S0920996416301682?via=ihub

[32] Qvist P, Christensen JH, Vardya I, Rajkumar AP, Mørk A, Paternoster V, et al. The SchizophreniaAssociated BRD1 Gene Regulates Behavior, Neurotransmission, and Expression of Schizophrenia Risk Enriched Gene Sets in Mice. Biological Psychiatry. 2017;82(1):62-76. Available from: https://www.biologicalpsychiatryjournal.com/article/ S0006-3223(16)32780-9/pdf

[33] Aghamaleki-Sarvestani Z, Vousooghi N, Tabrizi M, Alipour ME, Alaghband-Rad J, Mostafavi-

Abdolmaleky H, et al. Catechol-O-methyltransferase gene expression in stress induced and non- stress induced schizophrenia. Psychiatric Genetics. 2020;30(1):10-8. Available from: https://journals.1ww.com/psychgenetics/Abstract/2020/ 02000/Catechol_O_methyltransferase_gene expression_in.2.aspx

[34] Mcmeekin LJ, Lucas EK, Meador-Woodruff JH, Mccullumsmith RE, Hendrickson RC, Gamble KL, et al. Cortical PGC-1 $\alpha$-Dependent Transcripts Are Reduced in Postmortem Tissue From Patients With Schizophrenia. Schizophrenia Bulletin. 2015;42(4):1009-17. Available from: https://www.ncbi.nlm.nih.gov/pmc/articles/ PMC4903048/

[35] Bonaccorso S, Ricciardi A, Zangani C, Chiappini S, Schifano F. Cannabidiol (CBD) use in psychiatric disorders: A systematic review. NeuroToxicology. 2019;74:282-98. https://doi.org/10.1016/j.neuro.2019.08.002

[36] Vanduchova A, Anzenbacher P, Anzenbacherova E. Isothiocyanate from Broccoli, Sulforaphane, and Its Properties. Journal of Medicinal Food. 2019;22(2):121-6. Available from: 
UNDERGRADUATE RESEARCH IN NATURAL AND CLINICAL SCIENCE AND TECHNOLOGY (URNCST) JOURNAL Read more URNCST Journal articles and submit your own today at: https://www.urncst.com

https://www.liebertpub.com/doi/full/10.1089/ jmf.2018.0024

[37] Sugita Y, Makino T, Mizawa M, Shimizu T. Mugwort-Mustard Allergy Syndrome due to Broccoli Consumption. Case Reports in Dermatological Medicine. 2016;2016: 1-3. Available from: https://www.ncbi.nlm.nih.gov/pmc/articles/ PMC4961803/
[38] Cash-Padgett T, Jaaro-Peled H. DISC1 mouse models as a tool to decipher gene-environment interactions in psychiatric disorders. Frontiers in Behavioral Neuroscience. 2013 Sep; 7. https://doi.org/10.3389/fnbeh.2013.00113

[39] Bassett S, Barnett M. The Role of Dietary Histone Deacetylases (HDACs) Inhibitors in Health and Disease. Nutrients. 2014;6(10): 4273-301. https://doi.org/10.3390/nu6104273

\section{Article Information}

Managing Editor: Jeremy Y. Ng

Peer Reviewers: Jennifer Williams, Vinita Dhir

Article Dates: Received Oct 21 19; Accepted Jan 17 20; Published Feb 0320

\section{Citation}

Verhoeff NJ, Dhillon SK. The relationship between using cannabis, consuming sothiocyanate rich broccoli, and HDAC expression in schizophrenia: A research protocol. URNCST Journal. 2020 Feb 03: 4(2).

https://urncst.com/index.php/urncst/article/view/165

DOI Link: https://doi.org/10.26685/urncst.165

\section{Copyright}

(C) Natasha J. Verhoeff, Saihajleen K. Dhillon (2020). Published first in the Undergraduate Research in Natural and Clinical Science and Technology (URNCST) Journal. This is an open access article distributed under the terms of the Creative Commons Attribution License (https://creativecommons.org/licenses/by/4.0/), which permits unrestricted use, distribution, and reproduction in any medium, provided the original work, first published in the Undergraduate Research in Natural and Clinical Science and Technology (URNCST) Journal, is properly cited. The complete bibliographic information, a link to the original publication on http://www.urncst.com, as well as this copyright and license information must be included.

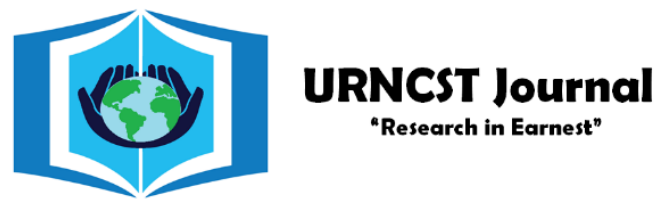

\section{Funded by the Government of Canada}

Do you research in earnest? Submit your next undergraduate research article to the URNCST Journal!

|Open Access | Peer-Reviewed | Rapid Turnaround Time | International | | Broad and Multidisciplinary | Indexed | Innovative | Social Media Promoted |

Pre-submission inquiries? Send us an email at info@urncst.com | Facebook, Twitter and LinkedIn: @URNCST

Submit YOUR manuscript today at https://www.urncst.com! 